\title{
Methodical approaches to the distribution of actual costs of railway infrastructure in conditions of fuzzy indeterminacy
}

\author{
Olena Zorina $^{1 *}$, Iurii Kalabukhin ${ }^{2}$, Nataliia Kameneva ${ }^{3}$ \\ ${ }^{1}$ Ukrainian State University of Railway Transport, Department of Marketing, Feierbakh Square 7, \\ 61050, Kharkiv, Ukraine \\ ${ }^{2}$ Ukrainian State University of Railway Transport, Department of Economics and Management of \\ Industrial and Commercial Business, Feierbakh Square 7, 61050, Kharkiv, Ukraine \\ ${ }^{3}$ Ukrainian State University of Railway Transport, Department of Economic Theory and Law, \\ Feierbakh Square 7, 61050, Kharkiv, Ukraine
}

\begin{abstract}
The authors propose methodical approaches to the distribution of actual maintenance costs for the station infrastructure of the track facility, as well as the signalling and communication facility of each station, as well as the distribution of cost measurements according to the type of work and the implementation costs in the organization of freight transportation.
\end{abstract}

\section{Problem Statement}

Currently, the development of market relations in the railway transport and intensification of competition raise the question of using the inefficient infrastructure, including such vivid examples thereof as low density areas and loss-making stations. Their operation requires a constant increase in the maintenance cost of outdated fixed assets, increased cost of materials, etc. This largely contributes to the increase of the primes cost of railway transportation, which, in turn, significantly reduces the level of socio-economic development and competitiveness of railways.

Today, when the reformation of the railway transport is in progress, and the competition in the transport services market increases, the railway industry should be adjusted to operating in the market economy, when in the transport services market the competition between different modes of transport intensifies, the volume of governmental orders for transportation is reduced, and the budget provides almost no funds for the development of the railway transport. The above facts make issues of ensuring sustainable socio-economic development of the Ukrainian railway transport under conditions of indeterminacy of its provision particularly relevant. Those cannot be solved without identifying ways to improve the efficiency of railway sections with a small volume of works, which accounts for about $60 \%$ of the total length of the railways.

\footnotetext{
* Corresponding author: market.kart.edu.ua@gmail.com
} 
The operation of low density railway sections and loss-making stations of the regional branches of Ukrzaliznytsia JSC, providing services for population and enterprises located in the area around these sections, causes quite significant losses to Ukrzaliznytsia and is accompanied by considerable organizational and managerial problems (such as maintenance and repair, staffing, traffic safety, etc.). Therefore, the essence of the problem is reducing the dependence of efficiency of the operation of railway transport on the operation of low density sections and loss-making stations.

At present, there is only an outdated definition of a low density section, while there is not at all a legal definition of a low density loss-making station is absent. There are also no methodologies for cost accounting and calculating for individual sections and stations. Therefore, the relevance of the topic of the study is doubtless. Many researchers focus on the problems of the formation and development of a transport potential; the following Ukrainian and Russian economists considered economic problems of providing effective operation of low density railway sections: I.M. Aksenov A.I. Butenko, B.V. Burkinskiy, O.O. Vasiliev, O.M. Gnennniy, OI Zorina, G.D. Eztutis, V.I. Kopytko, O.M. Kotlubay, M.I. Mischenko, V.I. Pasichnyk, P.A. Smagliy, I.S. Starchenko, Ye.M. Sich, V.V. Zhikhareva, M.Ye. Yushkov et al.

However, in view of the evident scientific interest to the issues of improvement of performance of the railway transport and a wide range of studies conducted in this line, the problem of ensuring economically effective operation of low density railway sections has not been considered in detail and needs to be addressed.

The purpose of the article is improving the methodological approaches to the definition of operating costs for the maintenance of freight stations, including loss-making ones, at the present stage of operation of the Ukrainian railway transport.

\section{Basic material of the research}

Operating costs of railways are determined using data provided by the structural unit of the regional branch of Ukrzaliznytsia JSC, to which a particular station belongs. In this case, the financial statement for the full calendar year preceding the year when the event is considered is used.

The presented data are combines according to the aggregated cost indicators that describe the estimated capacity volume of the freight station and the adjacent track areas it maintains. The composition of the analyzed aggregated performance indicators is presented in Table 1.

Table 1 Formation of cost measurements according to types of work and implementation cost in the organization of freight transportation

\begin{tabular}{|c|l|c|}
\hline $\begin{array}{c}\text { Name of } \begin{array}{c}\text { aggregated } \\
\text { measurements }\end{array} \\
1\end{array}$ & \begin{tabular}{c}
\multicolumn{1}{|c|}{ Cost item name } \\
Item No. in \\
the list
\end{tabular} \\
\hline \multirow{3}{*}{ Consignment } & \multicolumn{1}{|c|}{2} & 3 \\
\cline { 2 - 3 } & $\begin{array}{l}\text { Maintenance of scales and weighing instruments } \\
\text { Maintenance of buildings, structures, equipment and } \\
\text { inventory of the cargo and commercial management } \\
\text { facility }\end{array}$ & 3001 \\
\hline
\end{tabular}


continuation of the table1

\begin{tabular}{|c|c|c|}
\hline 1 & 2 & 3 \\
\hline & $\begin{array}{l}\text { Current repair of fixed assets of the cargo and commercial } \\
\text { management facility }\end{array}$ & 4011 \\
\hline & $\begin{array}{l}\text { Overhaul of the fixed assets of the cargo and commercial } \\
\text { management facility }\end{array}$ & 4012 \\
\hline & $\begin{array}{l}\text { Receipt and departure of trains at freight and marshalling } \\
\text { stations }\end{array}$ & 4032 \\
\hline & $\begin{array}{l}\text { Maintenance of buildings, structures, equipment and } \\
\text { inventory of the transportation facility }\end{array}$ & 4040 \\
\hline & $\begin{array}{l}\text { Current repair of the fixed assets of the transportation } \\
\text { facility }\end{array}$ & 4041 \\
\hline & Overhaul of the fixed assets of the transportation facility & 4042 \\
\hline \multirow{27}{*}{ Station rails } & $\begin{array}{l}\text { Current maintenance of station tracks and permanent } \\
\text { devices }\end{array}$ & 4102 \\
\hline & Current maintenance of access tracks & 4103 \\
\hline & Replacement of individual sleepers in station tracks & 4105 \\
\hline & Replacement of individual sleepers in access tracks & 4106 \\
\hline & Replenishment and replacement of ballast in station tracks & 4108 \\
\hline & Replenishment and replacement of ballast in access tracks & 4109 \\
\hline & $\begin{array}{l}\text { Replacement of individual rails, replacement and } \\
\text { replenishment of anticreeper braces and other elements of } \\
\text { the upper structure of the station tracks }\end{array}$ & 4111 \\
\hline & $\begin{array}{l}\text { Replacement of individual rails, replacement and } \\
\text { replenishment of anticreeper braces and other elements of } \\
\text { the upper structure of the access tracks }\end{array}$ & 4112 \\
\hline & Protection of tracks, crossings and artificial structures & 4113 \\
\hline & Maintenance of artificial constructions & 4114 \\
\hline & Maintenance of shelters & 4115 \\
\hline & $\begin{array}{l}\text { Overhaul of station tracks using old suitable materials of } \\
\text { the upper track structure }\end{array}$ & 4125 \\
\hline & $\begin{array}{l}\text { Overhaul of access tracks using old suitable materials of } \\
\text { the upper track structure }\end{array}$ & 4126 \\
\hline & Overhaul of the ballast bed of the station tracks & 4128 \\
\hline & Overhaul of the ballast bed of the access tracks & 4129 \\
\hline & Overhaul of artificial structures of the station tracks & 4131 \\
\hline & Overhaul of artificial structures of the access tracks & 4132 \\
\hline & Medium repair of the station tracks & 4134 \\
\hline & Medium repair of the access tracks & 4135 \\
\hline & Complex improving repair of the station tracks & 4137 \\
\hline & Complex improving repair of the access tracks & 4138 \\
\hline & Overhaul of machines, equipment mechanisms & 4153 \\
\hline & Depreciation of the upper structure of the station tracks & 4164 \\
\hline & $\begin{array}{l}\text { Depreciation of the ballast bed and artificial structures of } \\
\text { the station tracks }\end{array}$ & 4166 \\
\hline & $\begin{array}{l}\text { Depreciation of machines and mechanisms used in all } \\
\text { types of track repair }\end{array}$ & 4168 \\
\hline & Welding, grinding and other processing of rails & 4180 \\
\hline & Current repair of fixed assets of rail-welding trains & 4181 \\
\hline
\end{tabular}


continuation of the table1

\begin{tabular}{|c|c|c|}
\hline \multirow[t]{4}{*}{1} & 2 & 3 \\
\hline & Overhaul of fixed assets of rail-welding trains & 4182 \\
\hline & $\begin{array}{l}\text { Depreciation of fixed assets and other permanent tangible } \\
\text { assets of rail-welding trains }\end{array}$ & 4183 \\
\hline & $\begin{array}{l}\text { Current maintenance and routine maintenance of automatic } \\
\text { block signal devices }\end{array}$ & 4301 \\
\hline \multirow{13}{*}{$\begin{array}{l}\text { Shunting } \\
\text { diesel hour }\end{array}$} & Shunting at freight and marshalling stations & 4036 \\
\hline & $\begin{array}{l}\text { Shunting operation of electric locomotives in freight } \\
\text { transportation }\end{array}$ & 5022 \\
\hline & $\begin{array}{l}\text { Depreciation of dedicated shunting electric locomotives } \\
\text { operating in freight transportation }\end{array}$ & 5025 \\
\hline & $\begin{array}{l}\text { Maintenance of shunting electric locomotives operating in } \\
\text { freight transportation according to program TO-2, TO-3, } \\
\text { TO- } 4 \text {, TO-5, respectively }\end{array}$ & $\begin{array}{c}5027 \\
5029 \\
5031,5033\end{array}$ \\
\hline & Equipment of shunting electric locomotives & 5041 \\
\hline & $\begin{array}{l}\text { Shunting operation of diesel locomotives in freight } \\
\text { transportation }\end{array}$ & 5242 \\
\hline & $\begin{array}{l}\text { Depreciation of dedicated shunting diesel locomotives } \\
\text { operating in freight transportation }\end{array}$ & 5245 \\
\hline & $\begin{array}{l}\text { Maintenance of shunting electric locomotives operating in } \\
\text { freight transportation according to program TO-2, TO-3, } \\
\text { TO-4, TO-5, respectively }\end{array}$ & $\begin{array}{c}5247 \\
5249 \\
5251,5253 \\
\end{array}$ \\
\hline & Equipment for shunting locomotives & 5281 \\
\hline & $\begin{array}{l}\text { Current types of repair of shunting electric locomotives } \\
\text { operating in freight transportation according to program } \\
\text { PR-1, PR-2, PR-3, PR-3P, respectively }\end{array}$ & $\begin{array}{r}6241 \\
6243 \\
6245,6247 \\
\end{array}$ \\
\hline & $\begin{array}{l}\text { Current types of repair of shunting diesel locomotives } \\
\text { operating in freight transportation according to program } \\
\text { PR-1, PR-2, PR-3, PR-3P, respectively }\end{array}$ & $\begin{array}{c}6441 \\
6443 \\
6445,6447\end{array}$ \\
\hline & $\begin{array}{l}\text { Overhaul of shunting electric locomotives operating in } \\
\text { freight transportation }\end{array}$ & 6249 \\
\hline & $\begin{array}{l}\text { Overhaul of shunting diesel locomotives operating in } \\
\text { freight transportation }\end{array}$ & 6449 \\
\hline
\end{tabular}

Actual maintenance costs of the station infrastructure of the track facility for each station are determined depending on the total length of the station infrastructure and the actual specific maintenance costs per 1 kilometre of the station infrastructure track within an hour by the formula

$$
B_{j}^{t . f}=\frac{b_{t . f} \cdot L_{j}^{s t . \inf r} \cdot 365 \cdot 24}{1000}
$$

where $b_{t . f}$ is actual specific costs for the maintenance of 1 kilometre of track of the station infrastructure per one hour, UAH;

$L_{j}^{s t . \text { inf } r}$ is total length of the station infrastructure of the $\mathrm{j}$-th station, $\mathrm{m}$.

Actual maintenance costs of the station infrastructure of the signalling and communication facility for each station are determined depending on the total length of the 
station infrastructure and the actual specific maintenance costs per 1 kilometre of the station infrastructure within an hour by the formula

$$
B_{j}^{\text {s.c.f. }}=\frac{b_{\text {s.c.f }} \cdot L_{j}^{\text {st. inf } r} \cdot 365 \cdot 24}{1000},
$$

where $b_{\text {s.c.f }}$ is actual specific costs for the maintenance of 1 kilometre of the station infrastructure per hour, UAH.

The actual operation costs of shunting locomotives for each station are determined depending on the actual workload of the shunting locomotives by the type of traction (lochrs.) The actual specific costs per one loc-hour of operation of a shunting locomotive by the type of traction can be calculated using the formulas:

- diesel locomotive traction

$$
B_{j}^{\text {sh.d }}=b_{\text {sh.d. }} \cdot \sum M t_{j}^{\text {sh.d }},
$$

- electric locomotive traction

$$
B_{j}^{\text {sh.el }}=b_{\text {sh.el. }} \cdot \sum M t_{j}^{\text {sh.el }},
$$

where $b_{\text {sh.d }}, b_{\text {sh.el. }}$ are actual specific costs per locomotive-hour of work, respectively, of a shunting diesel locomotive and a shunting electric locomotive, UAH;

$\sum M t_{j}^{\text {sh.d }}, \sum M t_{j}^{\text {sh.el }}$ are actual volume of shunting workload of shunting locomotives and shunting electric locomotives, respectively, for the $\mathrm{j}$-th station, loc. hour.

The results of calculations are proposed to be included in a table containing the provisions summarized in Table 2.

Table 2. Results of calculations of actual cost for a railway station of the regional branch, thous. UAH

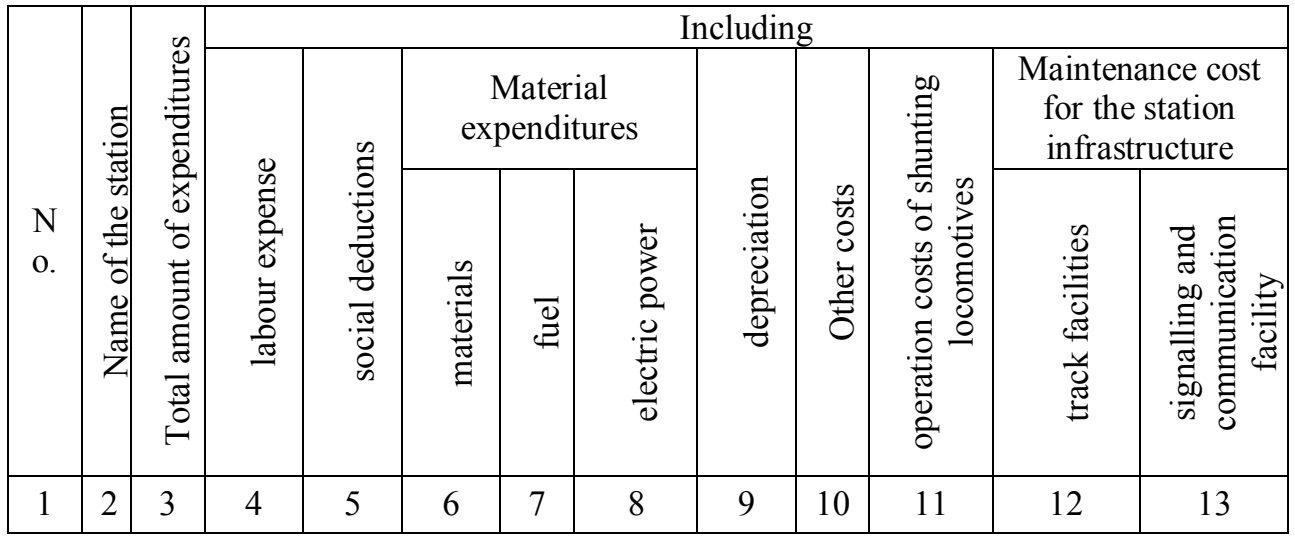

\section{References}

1 Law of Ukraine "On Railway Transport" - available at: zakon.rada.gov.ua.

2 Draft Law of Ukraine "On Rail Transport"] - available at: http://w1.c1rada.gov.ua/pls/zweb2/webproc4_1?pf3511=62929. 
3 Law of Ukraine "On Features of Creating a Public Joint Stock Company of Common Railway Transport".

4 Order "On Approval of the Ukrainian Railway Operating Rules" No. 411 of December 20, 1996 - available at: https: //zakon.rada.gov.ua/laws/show/z0050-97

5 Order "On Approval of the Operating Rules of Intersectoral Industrial Railway Transport of Industrial Enterprises" No. 1014 of October 1, 2009. - available at: https://zakon.rada.gov.ua/laws/show/z1166-09

6 Cost list for Main Types of Economic Activity of the Ukrainian Railway Transport (LLC Poligrafservis, 2011)

7 O.I. Zorina Effective Economy, 5, 2012, Access Mode: URL: http: //www.economy.nayka.com. ua / index.php? nomer_data $=3 \&$ year_data $=2012$ /

8 O.I. Zorina Internauka. 13(35), 2017,43-45 